\title{
高精度リモート溶接の可能性 ${ }^{*}$
}

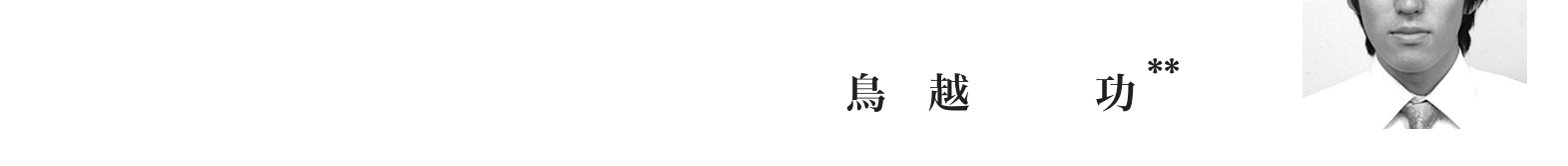

Possibility of the Precise Laser Remote Welding*

by TORIGOE Isao ${ }^{* *}$

キーワードレーザ溶接, 多関節ロボット，スキャナー, リモート溶接, テーラードブランク

\section{1.はじめに}

レーザ発振器の高出力化, ビームの高品質化に伴い, スキャナーを使用した長焦点の高速リモート溶接が可能 になった。リモート溶接は，ミラーを走査してレーザを 照射するので，ミラーのわずかな動きで，加工点が瞬時 に移動できる特徴がある。これにより, 空走時間がほと んど無くなり，タクトタイムの短縮が可能となる。ロボ ットやスキャナーの高精度化が進められており, リモー 卜溶接の突合せ継手や狭所など, 精度を必要とされる部 位への適用が検討され始めている.

実用化に当たって懸念されるのが, 生産現場は温度や 湿度など過酷な環境にあることが多く, カタログに示さ れたとおりの精度を引き出すのが難しいということであ る。また，単体としての精度は保証されているが，設備 としてシステムを構築した際の実力值は未知であり, 設 備メーカーのノウハウに依存するところが大きい.

本稿では, リモート溶接システムによるテーラードブ ランク材の溶接を目的として，多関節ロボット，スキャ ナーの位置精度を調査した結果を報告し，高精度リモー ト溶接システムの可能性について考察する.

\section{2. スキャナーの位置精度}

スキャナーの高精度化に当たって, 従来と大きく異な るのが, 制御方式がアナログ制御からデジタル制御へ変 わったことである。デジタル制御は，温度ドリフトが小 さく，ノイズの影響も受けにくいので, 繰り返し位置決 め精度が高い. Fig. 1 に示したデジタルスキャナーは, 新規に開発された光学式エンコーダが搭載されており,

$*$ 原稿受付 平成 23 年 7 月 14 日

** 前田工業株式会社 Maeda industries Co.Ltd
フルデジタル制御によって，アナログ制御と比較して， 高い位置再現性を実現している。

これは，生産設備を設計する際に非常に重要なことで ある。画像認識などを利用した位置補正は，スキャナー の原点を位置決めしているに過ぎない。リモート溶接に おいて, 実加工点の位置再現性はスキャナーの精度に大 きく依存するのである.

本実験では，デジタル制御のスキャナーを使用し，温 度ドリフトと繰り返し精度を調査した。

\section{1 温度ドリフト}

Fig. 2 は，スキャナーの冷却水温度を $25 \pm 5{ }^{\circ} \mathrm{C}$ で変化さ

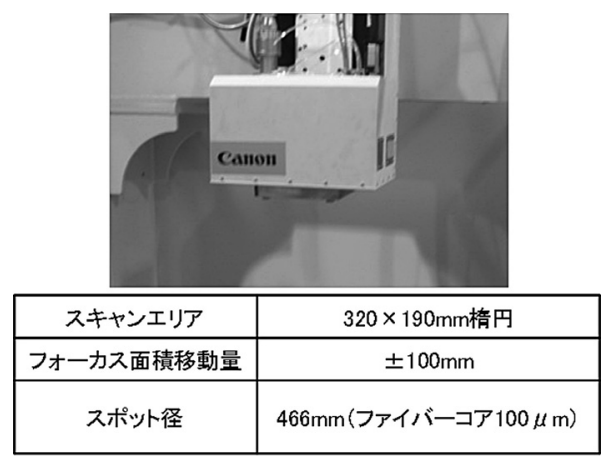

Fig. 1 スキャナーの基本仕様（CANON 製）

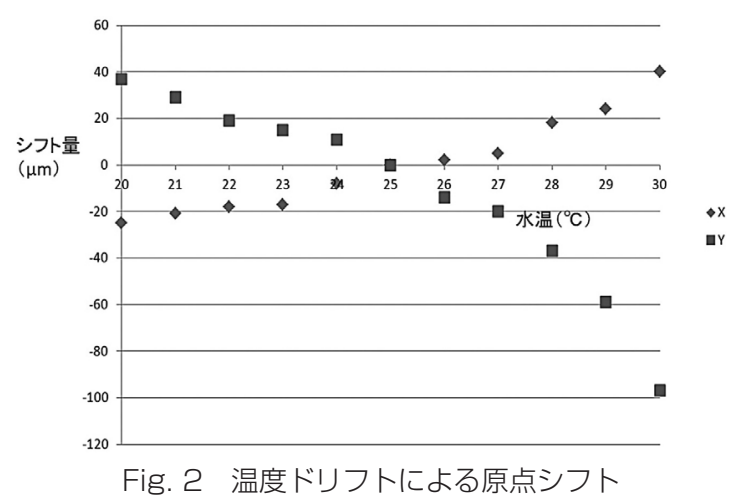

溶接学会誌 第 80 巻（2011）第 7 号 
Table 1 スキャナーの動作回数と繰り返し精度

\begin{tabular}{|c|c|}
\hline スキャナー動作回数 & 繰り返し精度 $(\mu \mathrm{m})$ \\
\hline 10 & 14 \\
\hline 100 & 16 \\
\hline 500 & 26 \\
\hline
\end{tabular}

Table 2 スキャナーの熱負荷の違いによる繰り返し精度 動作内容 繰り返し精度 $(\mu \mathrm{m})$ レーザを照射しながら スキャナ一動作10回 24 泠却水温度が $25^{\circ} \mathrm{Cから} 30^{\circ} \mathrm{C}$ 範囲で スキャナー動作10回

せた際の原点位置の移動量を軸別に示したものである. 移動量のレンジは $\mathrm{X}$ 軸で $65 \mu \mathrm{m}, \mathrm{Y}$ 軸で $130 \mu \mathrm{m}$ となり, $\mathrm{Y}$ 軸の方が大きく影響を受けている。また， X 軸，Y 軸共 に, 温度の上昇に伴い勾配は大きくなることが分かる.

\section{2 繰り返し精度}

Table. 1 は，スキャナーの冷却水温度を $25^{\circ} \mathrm{C}$ に一定と した際の, 繰り返し精度のレンジを示したものである. 動作回数の増加に伴いレンジが広がっている.モーター の発熱による影響で，僅かながら温度ドリフトが起きて いる.

Table. 2 はスキャナーへの熱的な負荷を変化させた際 の，繰り返し精度のレンジを示したもので，ミラーを介 したレーザによる熱影響と, 冷却水温度による影響を比 較したものである。結果として，レーザによる熱影響を 受けた状態では，繰り返し精度が $24 \mu \mathrm{m}$ であったのに対 し，冷却水温度が変化した場合は $67 \mu \mathrm{m}$ と，水温変化に よる影響が顕著に表れた。

これは，冷却水が光学系以外にも，ドライバーなど内 部の制御系も冷却しており，より直接的に影響を与える からである。したがって，スキャナーは冷却系をコント ロールすることが非常に重要で，これを達成すること で，外気温やレーザなどの影響を受けずに安定した精度 を得ることができる。

\section{3. ロボットの位置精度}

近年，レーザ加工など精密加工用に高精度ロボットが 開発され，テーラードブランク溶接などへの適用が進ん でいる。これらのロボットにスキャナーを持たせること で，スキャナーの加工範囲は広がり，3 次元のダイナミ ックな加工が可能になる。しかし，スキャナーは溶接・ 切断へッドに比べて重く, 重心もロボットの手首から遠 くなるため, 精度が出しにくい.オン・ザ・フライ加工 時には軌跡の精度も必要になり，スキャナーと組み合わ せるのは, より高精度なロボットが要求される.

本実験では，ロボットが指定位置に移動・停止後，ス キャナによる加工，の繰り返し動作を想定し，ロボット

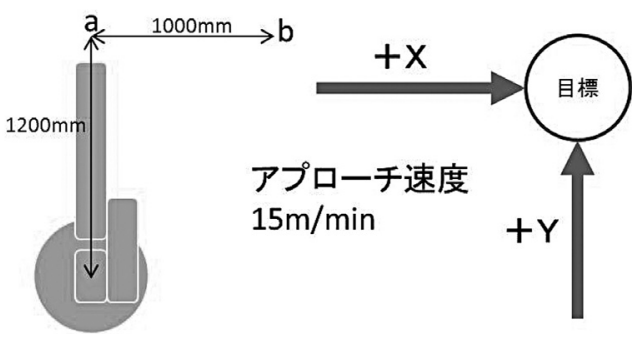

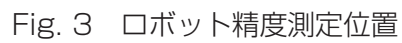

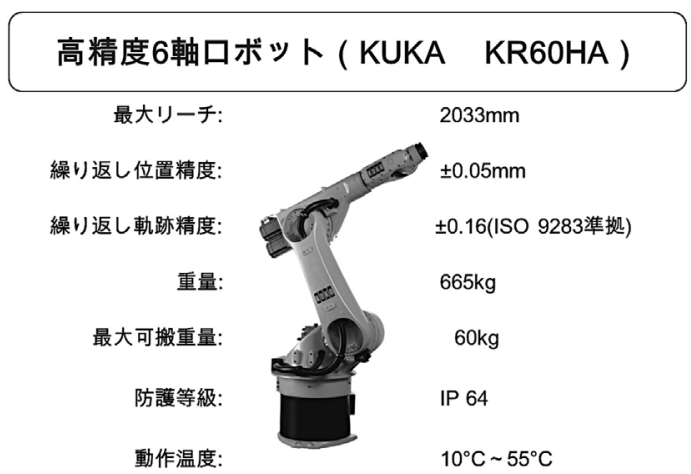

Fig. $4 \mathrm{KR} 6 \mathrm{OHA}$ 基本仕様（KUKA 製）

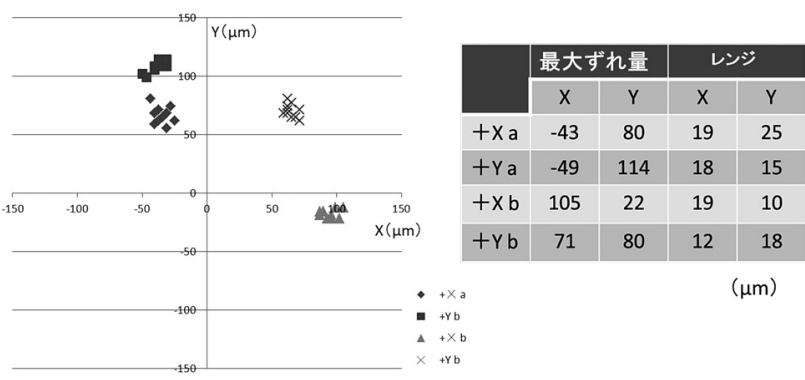

Fig. 5 ロボット位置決め精度

の繰り返し位置決め精度を調査した。

\section{1 繰り返し位置決め精度}

ロボットの精度を調査するに当たって, 留意すべきこ とがある、それは, ロボットは各軸の回転運動によって 動作していることである. 姿勢毎に使われる軸や回転量 が変化するので, 姿勢によっては精度が出にくく, 特異 点も存在する．特に，アームを稼働範囲の限界近くまで 伸ばすことはロボットに厳しく, 精度が低下する要因と なる。

本実験では，Fig. 3 に示すように，位置とアプローチ 方向による，精度の変化を測定した。使用したロボット は 6 軸多関節ロボットで，基本仕様を Fig. 4 に示す。

Fig. 5 は, 送り速度 $15 \mathrm{~m} / \mathrm{min}$ で目標点に10回アプロー チした際の, 目標点からの絶対值の最大ずれ量と, 繰り 返し精度を示したものである. 最大ずれ量は $114 \mu \mathrm{m}$, 繰 り返し精度は $25 \mu \mathrm{m}$ と, ロボットとしては, 十分な精度 を発揮した，最大ずれ量は，ロボット正面の a 点におい てはアプローチ方向の違いによる差は少ない.しかし， オフセットされて, 各軸の動きがより複雑となる $\mathrm{b}$ 点に おいては，Y座標で $50 \mu \mathrm{m}$ 以上の差が見られる，アプロ 一チ方向による違いも, a 点では $30 \mu \mathrm{m}$ 程度, $\mathrm{b}$ 点では 
Table 3 リモートテーラード溶接結果

\begin{tabular}{|c|c|c|c|c|c|}
\hline \multirow{2}{*}{\multicolumn{2}{|c|}{ 断面観察結果 }} & \multicolumn{4}{|c|}{ 狙いずれ $(\mu \mathrm{m})$} \\
\hline & & 0 & 100 & 200 & 300 \\
\hline \multirow{3}{*}{$\begin{array}{c}\text { ギャッッ゚ } \\
(\mu \mathrm{m})\end{array}$} & 0 & 0 & 0 & 0 & 0 \\
\hline & 100 & 0 & 0 & 0 & 0 \\
\hline & 200 & 0 & 0 & 0 & $x$ \\
\hline
\end{tabular}

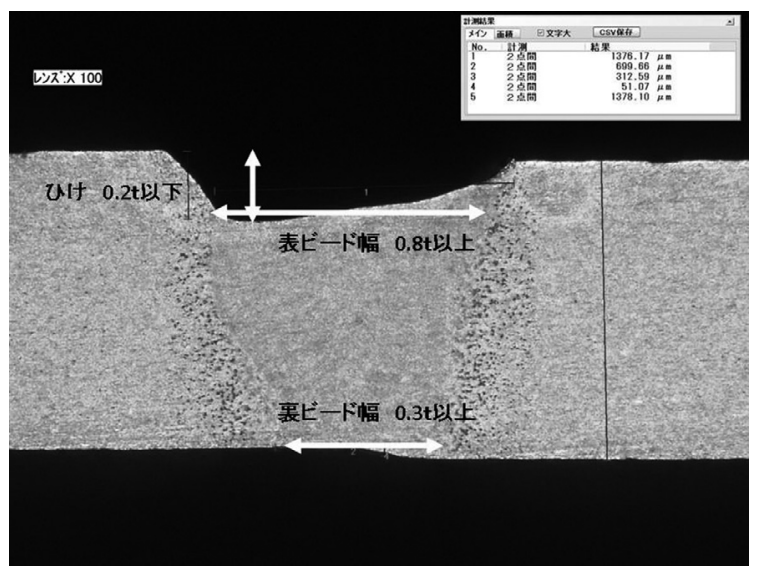

Fig. 6 ビード断面品質基準

$50 \mu \mathrm{m}$ 以上差が見られ，姿勢やアプローチ方向による精 度の変化が表れている。

プログラムを作成する際は，姿勢によってアプローチ 方向を選択し，より精度の高い動きを引き出すことで， 高精度な加工が可能となる。

\section{4. リモートシステムによるテーラードブ ランク溶接の品質}

リモート溶接は, 加工点にガスをかけず，レーザの照 射角も刻々と変化するため，加工へッドによる従来の溶 接とは状況が異なる．実績のある材質，板厚，継手であ っても，新たに品質を確認するのは必須の要件である.

これまでの調査により，スキャナーとロボットを組み 合わせた際の，複合的な繰り返し精度は，50 $\mu \mathrm{m}$ （片側 $25 \mu \mathrm{m})$ となることが分かった。ここに，ロボットによる 絶対值の最大ずれ量 $114 \mu \mathrm{m}$ を考慮すると， $140 \mu \mathrm{m}$ 程度 の狙いずれが起きることが予想される，また，ワーク精度 により, ギャップが $0.1 \mathrm{~mm}$ 発生することも予想される.

本実験では上記を考虑し，ハイテン材 $1.4 \mathrm{t}$ を用いて, 溶接線からの狙いずれを 0 から $0.3 \mathrm{~mm}$, 継手のギャップ を 0 から $0.2 \mathrm{~mm}$ まで変化させてリモート溶接を行い, 許容範囲を調査した。ロボットによる位置誤差を無視で きるよう，加工は XY ステージで行った．Table. 3 は, ビードの断面調査を実施した結果をまとめたものであ る.ビード断面の品質基準を Fig. 6 に示す。その結果，

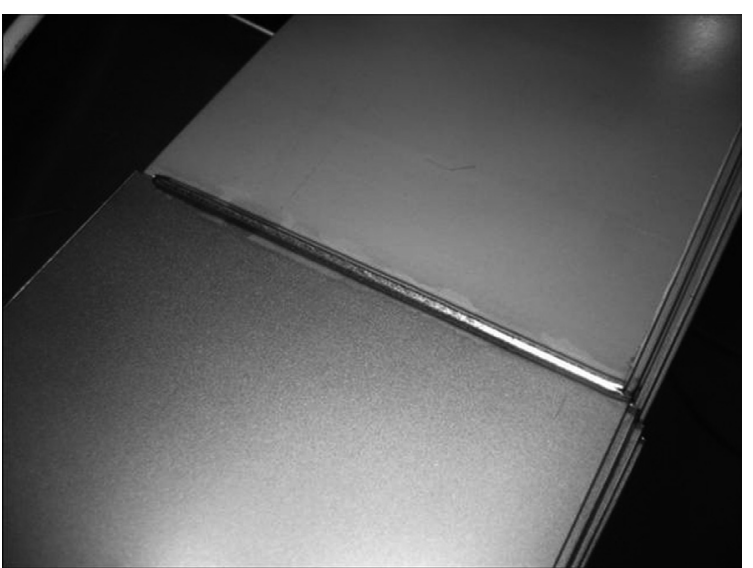

Photo 1 リモートテーラード溶接サンプル

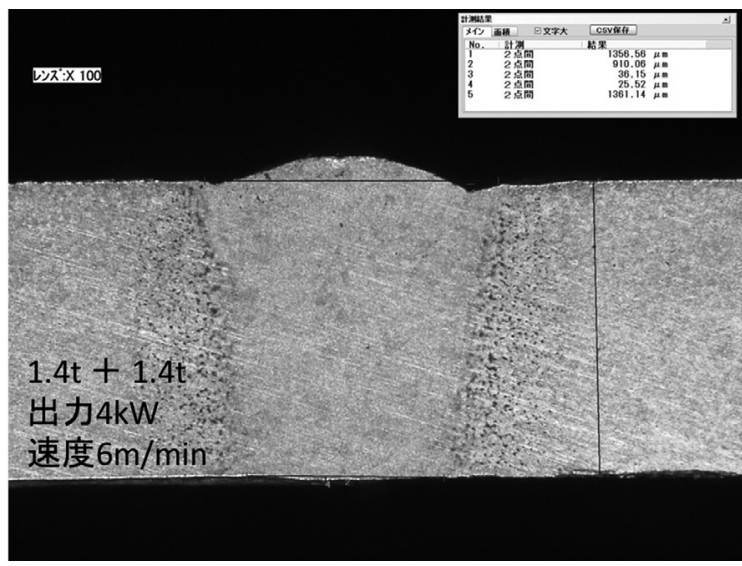

Photo 2 リモートテーラードブランク溶接断面

ビード断面はギャップ $0.1 \mathrm{~mm}$ まで品質基準を満たすこ とができた。ギャップが $0.2 \mathrm{~mm}$ でも，狙いずれ $0.2 \mathrm{~mm}$ まで許容でき，エリクセン試験は全て合格となった。従 来の溶接と遜色ない品質と言える。参考までに, Photo 1,2 に外観，断面を示す.

\section{5. まとめ}

本実験の結果から，リモート溶接によるテーラードブ ランク溶接の可能性が見えた。ロボットの位置誤差を画 像認識などで補正することで, 更に位置精度を向上させ る事が, 実用化への近道となる。しかし, ロボットの能 力を引き出し, 更に高い位置精度を確保できたならば, 補正システムに頼る必要が無くなり, システムを簡素化 し，コストダウンできるメリットが生まれる。

また，スキャナーを使用することは，スピニング，ウ イービングなどの高速で複雑な溶接が可能になり，溶接 手法を広げる事ができるので，ギャップ裕度拡大も期待 できる。

ロボットの絶対值精度の向上と, リモート溶接の溶接 性を追求することで, リモートテーラードブランク溶接 の実用化への道が開けるであろう。 